\title{
ANALYSIS OF THE ENVIRONMENT FOR MILITARY EDUCATIONAL SYSTEM FUNCTIONING AND ITS IMPACT ON THE PREPARATION OF CADETS FOR MILITARY PROFESSIONAL ACTIVITIES IN THE REPUBLIC OF BULGARIA
}

\author{
Venelin Terziev ${ }^{1}$ and Nikolay Nichev ${ }^{2}$ \\ ${ }^{1}$ Professor, Ph.D., D.Sc. (National Security), D.Sc. (Ec.), University of Rousse, Rousse, Bulgaria; \\ National Military University, Veliko Tarnovo, Bulgaria; University of Telecommunications and Post, \\ Sofia, Bulgaria, terziev@skmat.com \\ ${ }^{2}$ Colonel Associate Professor, Ph.D., National Military University, Veliko Tarnovo, Bulgaria, \\ nicheff@gmail.com
}

\begin{abstract}
The realisation of the goals and priorities of the National Security Strategy and the National Defence Strategy, as well as the realisation of the activities in the National Program "Bulgaria in NATO and in European Defense - 2020", and the Investment Plan-Program of the Ministry of Defense to 2020 set new tasks to the military educational system of the Republic of Bulgaria and in particular to the logistics officers preparation. The tasks have a complex character and include: improving the quality and competitiveness of the military education, increasing personal cadets' satisfaction in the process of training, and improving the organisation and content of the military professional training of the future officers. Military education is a complex, adaptable and flexible system which is developed in unity with the complementary system of the civic education in Bulgaria.

The target of research is the military professional activity, while the subject of research is the military professional activity of the Logistic Officers.

Methods of research: during the research a theoretical analysis of the military educational literature and of the normative documents was used; analysis and synthesis of the extent and the contents of the basic concepts, used in the elaboration; abstraction; substantiation; general conclusion and analogy.
\end{abstract}

Keywords: military training, training of cadets, higher education

\section{INTRODUCTION}

The realisation of the goals and priorities of the National Security Strategy and the National Defence Strategy, as well as the realisation of the activities in the National Program "Bulgaria in NATO and in European Defense - 2020", and the Investment Plan-Program of the Ministry of Defence to 2020 set new tasks to the military educational system of the Republic of Bulgaria and in particular to the logistics officers preparation. The tasks have a complex character and include: improving the quality and competitiveness of 
the military education, increasing personal cadets' satisfaction in the process of training, and improving the organisation and content of the military professional training of the future officers.

\section{ANALYSIS OF THE ENVIRONMENT FOR THE MILITARY EDUCATIONAL SYSTEM FUNCTIONING AND A CONNECTION BETWEEN MILITARY EDUCATION AND MILITARY PROFESSIONAL ACTIVITIES}

The functioning of the military education system in the Republic of Bulgaria is determined by the dynamic changes in: missions and tasks of the Armed Forces; legal framework; socio-economic relations; informational technologies; demographic development of the society.

The missions and tasks assigned to the Armed Forces require high morality and personal responsibility by military, effective leadership skills, language and computer skills, understanding psychology and social behaviour of people with different religions and cultures, knowledge of military-political and humanitarian crises, military conflicts and wars in the modern world, and knowledge of ecology and environmental protection.

The military education as an integral part of the Bulgarian system of higher education and directly depends on the current legislation in Bulgaria, namely the Law on Defence and Armed Forces of the Republic of Bulgaria, the Higher Education Act, the Act for the Development of the Academic Staff in the Republic of Bulgaria, as well as the acts of the National Assembly on higher military schools.

The rapid development of the information technologies requires a number of changes in higher military education. The entrance of qualitatively new educational technologies changes the nature of education as a whole. The relatively short-termed military education turns into a lifelong learning. It becomes more widely profiled than specialised. In this regard, a priority should not be learning and utilization of concrete examples of a new technique but forming a common military culture for the officers of different types and kinds of forces, which should provide an efficient military professional activity.

Bulgaria is in a period of deteriorated demographic development, which negatively affects the state of the military education system. The country's population decreases and the negative growth and intensive emigration leads to the inevitable reduction in a number of secondary school graduates, especially with the required level of mathematical and technical knowledge, which affects the potential candidates for higher military educational institutions.

The military educational system provides individual training of military staff in accordance with the Armed Forces training system, defined in the Doctrine of the Armed Forces of the Republic of Bulgaria (2012). The individual training includes training in national and foreign military academies, military high schools and vocational colleges. It provides basic knowledge and skills for military professional activities and is one of the main criteria for career development.

The military educational system provides the necessary education and skills for a successful career in the military profession and in different spheres of civil life after releasing from military commitments and contractual obligations for service in the armed forces (2013a).

A special characteristic of the military education system is that, unlike obtaining Bachelor degree in the national educational system, the military professional direction provides a close profiled and comprehensive military training in accordance with the acquired military specialty corresponding to the type of the army forces. This is determined to the fact that the future logistics officers hold positions at a tactical level in the military specialty, which imposes high requirements to their military professional training.

More detailed study on the issues of the cadets' and civilian students' motivation for training at the military educational institutions, and the relations between motivation for learning and satisfaction of training can be found in publications of E. Petrova (2016a), (2015a), (2013b).

\section{NATURE AND SPECIFICITY OF THE MILITARY PROFESSIONAL ACTIVITY}

The nature and specifics of the military professional activity is analysed in details by V. Madansky (2016b) who generally defines this activity as a dynamic system of interaction of servicemen with the outside world in the process of implementation of the assigned tasks.

Broadly, the military professional activity can be defined as a form of social activity with socio-political nature, through which the armed protection of the state interests is carried out, so to ensure favourable external socio-economic conditions for the country's development. In a narrower sense, the military professional activity is a process of implementation of the military tasks during the military service, studying and implementing weapons and military equipment, keeping duties, conducting warfare, etc. 
The military professional activity is specific in its structure, goals, motives, tasks, tools, techniques and methods, as well as external and internal conditions of implementation.

It can be performed on a different climatic conditions, land, air and water conditions, constantly changing environment, at any time of day and year, in the absence of relaxation and sleep. The modern weapons and military equipment are characterised by complexity, fast operative ness, and tremendous destructive power. Their studying and implementation is associated with particular impact of harmful and dangerous physical, chemical, biological, and social factors.

The terms of military professional activity are relation between serviceman and a certain set of circumstances, a complex reality, fixed at a certain interval of time during the performance of a specific task, which can be presented as a set of actions in an environment of high dynamics, development and extreme situations.

The structure of this activity has two sides: external (executive) and internal (psychophysiological) side. The external side is a system of professional actions and operations conventionally divided into tentative, analytical, forecasting, technological, protective and cooperative. The internal side is determined by professional preparedness and experience, moral and professional ideals, etc.

Nowadays, the preparation for effective management is an important factor in the commanders' professional activity. Military service is a combination of a variety of tasks with specifics. (1998) Some of the tasks require non-continuous, but limit expenditure of energy from logistics officer, others require continuous energy expenditure. Some cases require use of sensory-mental activity, others - use of external, practical activity which is related with predominant expending of physical energy. The military tasks can be hazardous and non-hazardous, labour intensive and relatively easy, simple and complex. Some of them encounter a good attitude of the staff from the beginning and are characterised by attractiveness, while the others are adopted with a certain internal resistance. Therefore, it can be done a generalized characterisation of varieties of logistics officers' activities which can be divided to several types. According to K. Todorkov any of them can be conditionally pointed as official activities (as work and duty), educational activities, and military activities which appear the most clearly in the practice of the army forces.

Work (daily activity related to the performance of household tasks) is an activity with relatively simple structure which is characterised with the performing of simple, repetitive actions and interactions with a relatively distribution of the workload. There are good conditions for its organisation and distribution to the people, linked to standardization, control and evaluation. Its management is relatively simple and can be done in algorithms.

Duty can be defined as a maintaining of a constant high alert. It consists of performing combat duties, sentry and domestic service. Activity of this type, despite the lack of major domestic activity, is extremely difficult. Its proper organisation and management requires good management skills by the commander.

Combat training activity represents an organized, focused and managed process, which resulted in acquiring knowledge, skills, habits, and personal qualities by military, which are necessary for maintaining constant combat readiness and combat assembling of the formations for participation in any military actions. It is characterised with peculiar conditions close to the combat environment, high level of mental and physical exertion, and intense cognitive activity. The didactic nature of the interaction between commanders and subordinates cannot be fully perform in a form of algorithms and requires possession and usage of high management skills and qualities.

Dynamic cooperation is a variety of complex group activity, on the basis of improvised interaction of the participants. Each warrior develops his behaviour on the basis of operative statements for the things which are done from the other warrior. He predicts behaviour and coordinates his own actions with the actions of other members of the group. As examples can be pointed the following activities: interactions during the academic classes and training, interactions during the operation of equipment, assistance, etc. The mutual statement of individual actions is a common feature for all the activities above.

All the activities of logistics officers are fully addressed to the positions that the graduates in "Logistic Organization and Management of Tactical Units" specialty, "Logistics and Activities with Fuel and Lubricants" and "Transportation and Movement" specializations can occupy. According to the Classification of the Military Positions, (2013c) the graduates in "Logistic Organization and Management of Tactical Units" specialty, "Logistics and Activities with Fuel and Lubricants" and "Transportation and Movement" specializations can occupy the positions: deputy company commander, commander of a platoon or a group, Head of department in a battalion, Head of a resupply module, Head and Head-assistant of logistics department and other logistical equivalent positions. 
The professional training of the future officers at the National Military University in Bulgaria is achieved through training in both military and civil specialties: military training in "Organization and management of tactical units for logistics" and civil training in "Business Logistics". In the both, cadets acquire the educational and qualification degree "Bachelor". The preparation for management activities in civil specialty is a result of training in five modules: "Basic subjects", "Management and Logistics" "Language training", "Physical training" and "Practical training". (2015b)

\section{CONCLUSION}

Military education is a complex, adaptable and flexible system which is developed in unity with the complementary system of the civic education in Bulgaria. It is designed to meet the needs of the Bulgarian Armed Forces from trained servicemen for the military professional activities. Nowadays, the preparation for effective management activity is an important factor in military professional activity.

\section{REFERENCES LIST}

Doctrine of the Armed Forces of the Republic of Bulgaria, Order of the Minister of Defence № OH57/30.01.2012 (2012).

Doctrine for Human Resources Management in the Armed Forces NP-1, Order of the Minister of Defence № $\mathrm{OH}-179$ / 03.06.2013, (2013a).

Petrova, E., (2016a) A Study on the Cadets' Satisfaction with Choice of Academic Specialty at the National Military University, Bulgaria, Socio-economic Analysis Scientific Journal, Department of Economics, St. St. Cyril and Methodius University, Bulgaria, / Volume 8 / Number 1.

Petrova, E., (2015a) Methodology on Study of Motivation for Education based on Opinions' Research of Cadets from Vasil Levski National Military University, Bulgaria, Socio-economic Analysis Scientific Journal, Department of Economics, St. St. Cyril and Methodius University, Bulgaria, Book 2 / Volume 8.

Petrova, E., Zegoicea, Andrei, (2013b) Comparative Case Study Regarding Cadet's Motivation Methodology, Revista Academiei Fortelor Terestre, Nicolae Balcescu Land Forces Academy, Sibiu, Romania, Vol. XVIII, Nr. 3 (71), Trimestrul III.

Madansky, V., (2016b) Fundamentals of the Survival in Extreme Conditions of Military Professional Activity. DSc Dissertation, Veliko Turnovo.

Todorkov, K. (1998) Psychological Aspects of Management Activity of the Commander, Ministry of Defence, S.

Classification of the Military Positions in the Directly Subordinate to the Minister of Defence and Armed Forces Structures, Decree № 84/ 26.04.2010, issue 24 by March 12, (2013c).

Nichev, N., Petrova, E., (2015b) Professional Training of Future Logistic Officers at the National Military University of Bulgaria, Sibiu, Romania, The 21st International Conference The Knowledge-Based Organisation, Nicolae Balcescu Land Forces Academy. 